children with liver disease because it provides justification for future studies on psoas muscle area, whose reduction is known as sarcopenia, now considered a biological correlate of frailty and strength impairment. ${ }^{3}$

The problems of Lurz study were it was conducted in a small cohort and the tools used were targeted at children as of 5 years old, whereas most children requiring a transplant are younger. In the near future, probably, different questionnaires like the PedsQL may be used additionally to assess different conditions, such as fatigue, in younger children.

Such new open patient assessment is a good opportunity to establish a new chronic disease interpretation and, in addition, to understand their actual impairment status and plan strategies aimed at reducing risks.

Most likely, only very few people have been able to define the meaning of frailty as precisely as Jorge Luis Borges, who, in his "Poem of the Gifts," wrote: "Let no one reduce to tears or reproach, this statement of the mastery of God, who, with magnificent irony, gave me at once both books and night."
Daniel Eduardo D'Agostino, M.D. Pediatric Gastroenterology-Hepatology \& Intestinal and Liver Transplantation Division

Department of Pediatrics

Hospital Italiano de Buenos Aires

E-mail address: daniel.dagostino@hiba.org.ar

http: / / dx.doi.org/10.5546/aap.2019.eng.356

To cite: D'Agostino DE. Frailty, more than a word. Arch Argent Pediatr 2019;117(6):356-357.

\section{REFERENCES}

1. Fried LP, Tangen CM, Watson J, Newman AB, et al. Frailty in older adults: Evidence of a Phenotype. J Gerontol A Biol Sci Med Sci. 2001; 56(3):M146-56.

2. Lurz E, Quammie C, Englesbe M, Alonso E, et al. Frailty in Children with liver Disease: A Prospective Multicenter Study. J Pediatr. 2018; 194:109-15.e4.

3. Lurz E, Patel H, Frimpong RG, Ricciuto A, et al. Sarcopenia in Children With End-Stage Liver Disease. J Pediatr Gastroenterol Nutr. 2018; 66(2):222-6.

\title{
The epistemology of introspection: the inner key to scientific research
}

\section{The illusory subject-object separation}

Making a superficial analysis, it seems that a scientist and the object of their investigation are separate entities; however, an in-depth analysis clearly shows that this is not the case because an investigator and the object of investigation are part of a whole, where they play the everlasting game of interchangeability. For example, an investigator and the laboratory animal they are studying are joined by the exchange of air he/she is breathing, among other things; i.e., investigators are a self-aware fragment of the world capable of observing and analyzing another fragment of the world. ${ }^{1}$ In general, investigators believe that natural laws are discovered by observing and analyzing a world that is "external" to them. However, investigators actually re-discover laws that have always been a part of them because, being a fragment of the world, they are permeated by such laws., ${ }^{2,3}$ Therefore, the research process is a kind of instrument that contributes to elucidating natural laws that have always resided "inside" the investigator, thus facilitating the passage from the shadows of the unconscious to the light of the conscious. Investigators, as fractals of the universe, contain every secret about the universe, but such secrets are written in a natural (genetic-symbolic) language of shapes, sounds, and movements, common to the entire natural (inorganic and organic) world but that is illegible for human consciousness, whose language is that of words (signs). It is necessary to translate from one language to the other so that such elucidation takes place. These languages match, so they correspond to one another because words (conscious language) evolve out of symbols (unconscious language), which, in turn, evolve out of natural shapes, colors, and movements (natural language). Thus, for example, Newton's law of universal gravitation was described 
(made aware) by Isaac Newton in 1687; however, animals and human beings have always "been aware" of the risk of falling from the top of the mountain because they knew the law of universal gravitation as part of their collective unconscious. $^{3-5}$

\section{Symbolic language as a reflection of the natural world}

The language of the natural world is not based on words (signs) but shapes, colors, and movements (pre-symbols), susceptible of being captured by senses and interpreted in an instinctive-intuitive manner when translated to a language of mental images (symbols) at a somatic subcortical level (unconscious), where all the natural "engineering heritage" is settled. In the case of human beings, a rational fragment of the natural world, such natural language is symbolically filed in their individual and collective unconscious and is expressed in their oneiric and artistic productions. Artistic language, a human variation of natural language, is capable of exploring the dimension of indescribability and focusing a set of inner feelings in an integrating perception (intuition). The perspective of humans in the setting of art is more like the original, pre-spoken perspective, typical of the prehistoric and child mind, i.e., from a time when the false subject/ object separation had not consolidated yet and when the reigning perception did not belong to linguistic categories. ${ }^{6}$

\section{Investigators as the main instrument of research}

In the light of the above, it is clear that the main instrument of research are investigators themselves, who, at the time of explaining a phenomenon, develop a hypothesis originated in the exercise of their fantasy-intuition and based on their unconscious ingredients (personal and collective). Such ingredients come from their natural unconscious file, and manage to go from the somatic subcortical level to the conscious plane (a memory in itself) at the expense of the research process. Only the subsequent confirmation of the scientific hypothesis validity by contrasting it against the facts of the world will distinguish, to a certain extent, whether such hypothesis was product of fantasy (mind-created unreality) or intuition (reality perceived through unconscious reasoning). However, given that the scientific method is based on induction (case collection), science is never able to determine the veracity of a hypothesis because it is impossible to collect the total necessary cases to confirm it, but only a sufficient number of cases can be collected to establish its apparent truthfulness (likelihood), as long as its falsehood is not demonstrated. Therefore, the difference between what has been created by the mind (fantasy) and what has been re-discovered by it (intuition) is always provisional; this way, fantasy and intuition may be encompassed by a single mental activity called imagination, which is always fostered by the unconscious and is indispensable for scientific research development. Such research instrument, made up of investigators' consciousness and active imagination, requires a connection with two elements; on the one side, the object of investigation and, on the other side, their unconscious knowledge, which is part of the world's natural file and is based on at least two enabling conditions: ${ }^{-9}$

- The exercise of empathy.

- A clear conscious.

Empathy is usually defined as the ability to understand the feelings of another person; however, such ability may be experienced even in relation to animals and things (universal empathy). The experience of empathy requires, on the one hand, opening up to recognize others (subject or object), and patience to temporarily experience "first hand" an external situation or status in order to understand it and then "walk away" from it to analyze the experience with the greatest objectivity possible. The empathetic act involves extending the experience horizons, erasing the arbitrary boundaries of the ego, space, and time. ${ }^{10}$

Empathy decodes a natural language (indescribable) at a limbic (unconscious) level, thus facilitating its passage to a language made up of words (conscious). Empathy would therefore be the mental process that achieves the translation from the natural language (worldly images) into the conscious language (words), going back and forth to symbolic language (mental images). This means that intuitive thinking involves a double translation, from the language of things (natural) into that of mental images (symbolic) and, finally, into that of words (signs). This is precisely the rationale of the hypothesis that investigators' exposure to settings with a high symbolic significance, such as natural surroundings or places filled with works of art, may facilitate the passage of content from the unconscious to the conscious field through empathetic stimulation, 
which would therefore provide them with the raw materials to work with imagination (fantasyintuition). In relation to the conscious awareness concept, it implies that investigators need to achieve, through self-observation and to the extent possible, a conscious level that is free from mechanical mental processes (mental noise), such as the identification of negative emotions (fear, envy, greed, prejudices) or an excessive attachment to the ego (arrogance, selfishness), because these drive to tightness of mind, loss of critical objectivity, free thinking, and empathetic and creative mental ability. Given that an individual's evolutionary level conditions their comprehension, scientists' inner development would therefore foster an adequate unconsciousconscious empathetic flow and, consequently, a fruitful ability to exercise introspection and shape ideas.

\section{CONCLUSION}

The epistemology of introspection claims that, given that investigators are the main instrument of research and that the laws of the natural world lie in their unconscious, their ability to develop empathy and a clear conscious based on their personal growth, would result in a better unconscious-conscious connection and, therefore, a better scientific production.

Carlos G. Musso, M.D. E PhD. Instituto Universitario del Hospital Italiano de Buenos Aires, Argentina http: / / dx.doi.org/10.5546/ aap.2019.eng.357

To cite: Musso CG. The epistemology of introspection: the inner key to scientific research. Arch Argent Pediatr 2019;117(6):357-359.

\section{REFERENCES}

1. Suzuki D, Fromm E. Budismo zen y psicoanálisis. Mexico, D.F.: Fondo de Cultura Económica; 1964.

2. Fromm E. El lenguaje olvidado. Barcelona: Paidos; 2012.

3. CirlotJE. Dictionary of symbols. $2^{\text {nd }}$ ed. London: Routledge; 1971.

4. Jung CG. Arquetipos e inconsciente colectivo. Barcelona: Paidos; 1970.

5. Jung CG. Símbolos de transformación. Barcelona: Paidos; 1963.

6. Musso CG. La intersección de las paralelas: arte y ciencia en un único proceso cognitivo. Hacia una nueva forma de investigar. Rev Hosp Ital B Aires. 2012;32(1):1-2.

7. Musso CG, Dricas D, González-Torres H. Apicación del arte en la investigación científica: fundamentos de un método original para su utilización. Arch Argent Pediatr. 2018;116(5):353-8.

8. Nicoll M. Comentarios piscológicos sobre las enseñanzas de Gurdieff y Oupensky. London: Kier; 1944.

9. Farber M. Husserl. Buenos Aires: Losange; 1956.

10. Musso CG, Enz P. Arte y naturaleza humana XII. Rev Hosp Ital B Aires. 2013;33(2):71-2. 